\title{
The Effectiveness of Jatim Mengajar Program as an Agent of Change for Remote Schools
}

\author{
Moch. Dedik Setiawan \\ Education Management Program \\ Universitas Negeri Surabaya \\ Surabaya, Indonesia \\ mochded.setiawan@gmail.com
}

\begin{abstract}
Jatim Mengajar program is a teacher sending program to remote schools in East Java for 1 year. The purpose of this study is to find out the effectiveness of the East Java Teaching program as an agent of change that is reviewed from the stages of planning, organizing, actuating, to controlling. The research method uses descriptive qualitative with type of case study whose data collection techniques use direct observation, in-depth interviews, and documentation studies. The results of this study indicate that Jatim Mengajar program has been able to map the potential and constraints faced by remote schools and the surrounding community environment and is able to provide solutions in the form of innovation of education and community empowerment. However, not all of them have been able to be resolved within a year, so this program still requires follow-up in the form of cooperation with several related parties in the region.
\end{abstract}

Keywords-the effectiveness of program; agent of change; remote schools

\section{INTRODUCTION}

Education in its essence is the basis for every individual as an Indonesian citizen. Based on article 28 of the 1945 Constitution, it was explained that human rights consist of the right to life, the right to family, the right to communicate and obtain information and the right to education. Educational roles can also be considered as investment and human capital in spurring growth economy [1]. But looked at the condition of Indonesia's territory which is geographically broad and has a very heterogeneous socio-culture, so that the implementation of education in several regions still has various problems, especially in remote areas [2].

Several problems in the implementation of education, especially in remote and disadvantaged areas include a shortage of teachers, unbalanced distribution, substandard qualifications, lack of competency, and discrepancies between educational qualifications and the fields under study [3]. Another obstacle is limited educational facilities and infrastructure and difficult road access. According to law article 31 paragraph 1 , it is explained that every citizen has the right to education, this certainly needs to be given more attention and improvement from the government so that national development goals can be carried out properly.
Efforts that have been made by the government to overcome the education gap in remote areas, namely making SM3T programs. The SM3T program is an educational scholarship program to participate in the acceleration of the development of the foremost, outermost, and underdeveloped regions for one year as the preparation of professional educators who will later be followed by the Teacher Professional Education Program. According to research on teacher professional curriculum management for the foremost, outermost, and disadvantaged regions in Surabaya State University, the results show that there is a positive impact on the competence of teacher profession participants and the region where the tuition takes place for a year [4].

The positive impact of the SM3T program has made Yayasan Dana Sosial Al-Falah (YDSF) inspired to organize the Jatim Mengajar Program through collaborative relations with UNESA. The Jatim Mengajar Program is intended to help overcome teacher shortages, while preparing professional teacher candidates who are strong, independent, and have a caring attitude towards others, and have the spirit of educators to educate children of the nation so that they can progress together to achieve the noble ideals mandated by the founders nation. Participants were educational scholars who had not yet served as teachers, both as civil servants and permanent teachers of the foundation to be assigned for one year in remote East Java. The number of assignments is spread across ten districts.

Teachers of Jatim Mengajar are expected to be agents of change for the school and the community in their place of duty. Agent of changes are individuals or groups who have a large influence in making decisions for change and introducing new programs, creating strategies for cooperation with the public, sometimes also acting as organizational restructures and innovators [5]. The existence of assignments as agents of change makes Jatim Mengajar teachers not only able to concentrate in terms of teaching in schools but also must be able to create innovations in the fields of education, community empowerment, preach Islamic religion, and be able to prepare the next generation of the environment.

The innovation must also be based on the achievement of goals and objectives that have been set in advance [6]. The process of delivered or communicated to the social system at a certain time will also affect the success of an innovation. 
Whereas for community empowerment it is demanded not only to enrich knowledge, but also to improve their skills [7]. In this research the effectiveness of Jatim Mengajar program will be based on 4 management functions which include the stages of planning, organizing, actuating, and controlling [8].

Based on this background, the researchers wanted to find out the effectiveness of the Jatim Mengajar program as a change agent for remote schools that was reviewed from the stages of planning, organizing, actuating, and controlling.

\section{METHOD}

This research method uses descriptive qualitative with a type of case study that explains the management of the Jatim Mengajar program which is reviewed from the stages of planning, organizing, implementing, and monitoring. The data collected is not in the form of numbers, but rather words, sentences, paragraphs, interviews, notes, memos, and other official documents.

The places in this study were MI Muhammadiyah Watuagung and Krecek hamlet society, Trenggalek. The researcher acted as a teacher assisting the Jatim Mengajar program while for the informants were the director of the Jatim Mengajar Program, the Jatim Mengajar lecturer, the headmaster, the teacher, community leaders, guardians of students, and students. This research was conducted from 1 August 2017 to 31 July 2018.

The techniques used in collecting data in qualitative research are in-depth interviews, direct observation, and document studies. The interview technique is used to determine the response of the informants related to the Jatim Mengajar program starting from the stages of planning, organizing, actuating, to controlling. Direct observation techniques are used to determine the potential and constraints found in schools and the community environment so that later can be given further action in the form of innovation in the field of education and community empowerment. For document study techniques obtained from journals, tabloids, magazines, books, and others.

The data analysis technique in this study through three paths namely: (1) data reduction, (2) data presentation and (3) conclusions (temporary conclusions, verification of final conclusions). In this study there are 4 aspects that must be tested, namely credibility (internal validity), transferability (external validity), dependability (reliability), and confirmation (objectivity) [9].

\section{RESUlTS AND DisCUSSION}

The Jatim Mengajar program planning activity begins with the YDSF who conducts surveys to school places and the surrounding community environment. The survey is based on the criteria of remote schools and lack of teachers. The second stage is to select participants who become teachers. The selection phase includes administration, written tests, interview tests, micro teaching, and reciting. In 2017, there were 125 participants who registered and only 10 people passed. After the graduation was declared, the third stage was the precondition in the UNESA LP3M building whose activities were in the form of material debriefing related to curriculum, learning models, learning media, social, scout, health, etc.

After that in the fourth stage, the participants will receive survival training at one of the Jatim Mengajar teacher assignments, namely in Rapah ombo hamlet, Jombang. In that place, the Jatim Mengajar teachers was asked to stay in touch with the residents, see the condition of education at SDN Pojok Klitih 3, and receive material guided by an instructor by delivering it in the form of a game.

The initial stages of organizing the Jatim Mengajar program were the division of assignments to 10 participants. The rules are based on two things, namely the distance between the house and the place of duty and culture of the local community. The next stage is conducting observations to find out the potential and constraints contained in the assignment. Constraints at MI Muhammadiyah Watuagung, Trenggalek are divided into two groups, namely schools and the environment. For schools, the constraints include limited educational facilities and infrastructure, low teacher professionalism, and lack of school finance. Whereas for the environment includes the low economic conditions of the community, lack of understanding of Islam, difficult road access, and lack of water. The potential that can be developed is the character of students who are obedient and polite towards the teacher, high community participation in each activity, and cool environmental conditions.

At the stage of the Jatim Mengajar activities program at MI Muhammadiyah Watuagung, Trenggalek is divided into three main areas namely education, religious morality, and society empowerment. These three fields will be implemented and developed using the concept of innovation.

In the field of education, Jatim Mengajar teacher carry out an innovation related to learning activities. The activities include: HOS, project classes, robotics training, watching inspirational films, and tutoring. HOS stand for healthy, outbound, and sport. The purpose of this activity is to overcome the problem of teacher vacancies on Friday and Saturday. Based on its name, this educational innovation will be divided into three main activities. Healthy activities in the form of health counseling from the Slawe Health Center and voluntary work to clean the school environment. For outbound activities, the form of activities is in the form of interactive games and scout training. Whereas sports, the form of activities is in the form of sports and natural roaming around.

Project class is an innovation program in education that aims to train students to make products that are useful in their daily lives. The education sector made in project class activities includes a variety of things, namely science, food, crafts, and technology. In its implementation, students will be divided into two large groups consisting of juniors and seniors. For the senior project, the members consist of students from grades 4 to 6 while the junior project consists of students from grades 1 to 3 . Several project class activities that have been held at MI Muhammadiyah Watuagung include: making water candles, making natural insect repellent, making jasuke, planting peanuts green, making paper bikes, and water purification. 
The watching inspirational film are carried out after the project class, namely on Saturday starting at 09.00 until 11.00 WIB. The selected films are divided into several groups, namely education, religion, figure, and entertainment. Each week a different film will be screened and after screening students will be asked for their opinions about the story, character, figures, and the mandate contained in the film.

Robotics training was made to follow up on the project class program that had been implemented at MI Muhammadiyah Watuagung. The activity is divided into two namely training in making fire fighting robots and competitions, so the program is held for two days. The instructors came from the UNESA Rengganis Robotic Club team. The school supervisor also attended the event to see the fire fighting robot competition.

Tutoring aims to foster student intellectual and psychological development based on reality in the process of teaching and learning activities in schools. The tutoring activities carried out at MI Muhammadiyah Watuagung are divided into 3 learning packages, namely (1) calistung packages that will be implemented by first grade students and students who cannot read fluently, (2) material packages to be implemented by second to fifth graders, and (3) national exam packages to be carried out by sixth grade students. Subjects taught in tutoring include Mathematics, Science, Indonesian, Social, and English.

In the field of religious morality, the Jatim Mengajar teacher carries out an innovation that is related to the activities of understanding Islam to students. As for the activities include: reciting competition and five-time prayer cards.

The Qur'anic competition is a learning innovation that aims to add insight into students' religion, especially in the material of the Qur'an and Jurisprudence. In the implementation of MI Muhammadiyah Watuagung students will be divided into two groups, namely the volume team and the juz team. The Qur'anic competition activities include: (1) writing and explaining material about the Qur'an and Fikih, (2) giving tests in the form of memorization, assignments, and practices on a weekly basis, (3) assessing students using report card systematics whose assessment includes: attitude, attendance, recitation, and material tests, (4) Giving appreciation in the form of prizes to students who get the 3 highest scores for each team at the end of the month.

The five-time prayer card is an innovation in realizing students' awareness of their obligation to perform fard prayer which is relatively low and it can even be said that they have never run the service. It is hoped that with this card, students can become pioneers in the surrounding environment. They will be the front guard to invite their families and communities to perform fard prayer.

In the field of society empowerment, Jatim Mengajar teachers carry out an innovation related to two activities, namely the provision of assistance and community economic training. The activities include: stocking of qurban animals, bekam, and training in making feed centrates.

The distribution of qurban animal stocking is an activity of sending and distributing qurban meat for YDSF to people in remote areas. In its implementation at MI Muhammadiyah Watuagung, the number of goats that will be sacrificed is seven. While the number of people entitled to qurban meat is 135 .

Bekam stands for underprivileged rice. This program is assistance from YDSF in the form of giving $5 \mathrm{Kg}$ of rice to five poor people in Krecek Hamlet. In its implementation, the YDSF did not directly provide rice assistance but in the form of money with a nominal value of Rp. 60,000 per person.

The training in making feed sentrat was motivated by the anxiety of Krecek Hamlet residents who had difficulty in finding food related to the food during the dry season. This study aims to find alternative feeds besides grass, improve the nutrition of livestock so that when sold the price is high, and in the long term can be used as an alternative livelihood by the residents of Krecek Hamlet. In addition, with this training, it is expected that residents can utilize the yield of corn harvest waste for animal feed.

The stages of controlling in the Jatim Mengajar program are carried out by conducting monitoring and evaluation conducted by lecturers from UNESA twice a year. The assessment criteria are that the first six months focus more on school activities and the following six months, change to community empowerment. The method of assessment is by giving a questionnaire to the school and community representatives, besides that it is also done using the interview method.

YDSF also visits once a year to find out the conditions and progress of the work program of each East Java Teaching teacher in his assignment. Even though it's very simple, YDSF always communicates intensively with Jatim Mengajar teachers every week through whatsapp and facebook media. In addition there are also first-half work meeting activities held in Sampang with the presentation agenda of the implementation of work programs that have been achieved and the provision of material about community empowerment from an instructor.

The stages of the Jatim Mengajar Program planning, which starts from site surveys, assignment procedures, participant selection, material training to training which states that the planning process must begin with goal setting, setting goals, identifying choices until they are formed selected plan [10].

For the stage of organizing the Jatim Mengajar Program in the form of placement of teachers in their assignment area by considering certain criteria, the act of planning and implementing the organization structure. It is the process of arranging people and physical resources to carry out plans and accomplishing obtective organizational [11]. Then after the placement of the Jatim Mengajar teacher, then they are asked to observe the potential and constraints that exist in the place of assignment. This starting from the stages of detailing all the work that must be carried out, the division of labor, and determining further policies.

The stages of implementation are divided into two areas, namely education and community empowerment by 
promoting the concept of innovation. Innovation is a creative process where two or more existing concepts are combined in several new ways to produce a configuration people don't know yet [12].

While at the controlling stage in the form of monitoring and evaluation and the existence of semester performance meetings to see how much the progress of the performance of of Jatim Mengajar teachers, which states that controlling is a systematic effort to set standards of implementation with planning objectives, designing a feedback system, comparing activities with established standards, and measuring deviations [13].

The existence of innovation in every Jatim Mengajar program in overcoming problems makes Jatim Mengajar teachers able to make changes in their assignments. Successful change in the organization should follow four steps, (1) the desire to change (desire of change), before change occurs each individual must feel a need, can be in the form of shortcomings and dissatisfaction so far and the existence the desire to improve, (2) disbursement (unfreezing), which through approaches by reducing threats and rejecting so that each individual is ready to change, (3) changing which includes giving changes to each individual through new learning in attitude in this case, workers are given new information, new behavioral models, and new ways of seeing things so that workers learn with a new attitude, and (4) refreezing new changes to make it permanent [14].

In the Jatim Mengajar program that is held for one year, not all potential can be developed and not all obstacles can be solved. For example, in the hamlet of Krecek, the Jatim Mengajar teacher is still not able to overcome the difficulties of water, so it requires follow-up in the form of cooperation with several related parties.

\section{CONCLUSION}

The effectiveness of the Jatim Mengajar program has been carried out based on 4 stages, namely planning which contains location survey activities, teacher selection, material briefing, and survival training. For the organizing stage starts from the Jatim Mengajar placement activities Teaching to task areas based on certain criteria and conducting observations to find out potentials and constraints so that a work program design can be arranged for a year. Then for the implementation phase, it is divided into three fields, namely education, religious morality, and community empowerment, both of which prioritize the concept of innovation. Whereas for the final stage, controlling is carried out by monitoring and evaluating by lecturers twice a year and a semester work meeting is held to determine the progress of the work program for each Jatim Mengajar teacher to teach. However, an unresolved obstacle was found, namely the water crisis, so that it needed follow-up in the form of cooperation with several related parties.

\section{REFERENCES}

[1] Ehrenburg, Ronald G, \& Robert S. Smith. Modern Labor Economic Theory and Public Policy. 1999
[2] Eka Saputra, Fetiana. Persepsi Mahasiswa Program Studi Kependidikan Universitas Negeri Surabaya Terhadap Program Sarjana Mendidik di Daerah Terdepan, Terluar, dan Tertinggal. Jurnal Swara Bhumi,48-56. 2017

[3] Yustina., D. \& Dahnilsyah. Creativity of SM3T Participants at Riau University in Developing Knowledge Using Project-Based Learning at Lany Jaya, Papua, Indonesia. Australian Journal of Basic and Applied Sciences, 9 (31),530-536. 2015

[4] Diat, Lantip Prasojo. Manajemen Kurikulum Program Profesi Guru Untuk Daerah Terdepan, Terluar, dan Tertinggal di Universitas Negeri Yogyakarta. Jurnal Pendidikan dan Kebudayaan, 2 (1),39-53. 2017

[5] Nanus, Burt and Stephen M. Dobbs. Leaders Make Different Strategies for Meeting the Non Profit Challenge, San Francisco: Jossey bass, 1999.

[6] Boettcher Judith V. Faculty Guides for Moving Teaching and Learning to the Web. USA: Leage for Innovation in the Community College. 1999.

[7] Fukuyama. Trust : The Social Virtues and the Creation of Prosperity. Free Press, ISBN 0-02-910976 0. 2015

[8] Terry, George R. The Principles of Management, Third Edition, Homewood Illinois: Richard Irwin. 1960

[9] Miles, M.B \& Huberman A.M.. Qualitative Data Analysis a Sourcebook of New Methode. London: Sage Publications. 1984.

[10] Sallis, Edward.. Total Quality Management im Education, terjemahan Yogyakarta IRCiSoD. 2006.

[11] Boone, Louise E., David L. Kurtz. Principles of Management, New York: Random House. 1984.

[12] Gerald Zaltman, Robert Duncan, Johny Holbek. Innovation and Organization. Willey-Interface Publication John Willey and Son. New York, London, Sydney, and Toronto. 1973.

[13] Robert J. Mockler. The Management Control Process, Englewood Cliffs, Prentice Hal. 1996

[14] Kurt, Lewin. Field Theory in Social Science: Selected Theoretical Papers, New York Harper. 1951 